\section{Weight loss diets advertised in non-scientific publications}

\author{
Dietas para perda de peso \\ anunciadas na imprensa leiga
}

Olga Maria Silverio Amancio 1 Daniela Maria Alves Chaud 1

\footnotetext{
${ }^{1}$ Escola Paulista de Medicina, Universidade Federal de São Paulo, São Paulo, Brazil.

Correspondence O. M. S. Amancio Escola Paulista de Medicina, Universidade Federal de São Paulo. Rua Botucatu 703, São Paulo, SP 04023-062, Brasil. omsamancio.dped@epm.br
}

\begin{abstract}
Weight-loss diets advertised in mainstream non-scientific publications and targeting the adult female public were evaluated in relation to total energy value, macronutrients, calcium, iron, vitamins A and E, and cholesterol content, as well as the presence of information regarding the duration of diets, fluid intake, physical activity, and maintenance diets. Two publications were selected, considering periodicity, circulation, readership, and years in publication. The Virtual Nutri software was used to evaluate the nutrients of 112 diets. Micronutrient content was compared to the Dietary Reference Intakes. All diets were inadequate in at least one of the evaluated items. Less than $25.0 \%$ of the diets presented adequate macronutrient distribution. Calcium, iron, and vitamin E were also predominantly inadequate (85.7, 97.3, and 91.9\%, respectively). Non-scientific publications should not be allowed to advertise weight-loss diets. In addition, their chemical composition is inadequate and they are not accompanied by important instructions for such therapy.
\end{abstract}

Diet; Weight Loss; Nutritive Value; Publications

\section{Introduction}

Obesity and overweight are becoming more common every day in both developed and developing countries. In Brazil, cross-sectional studies show that from 1974 to 1997 there was an increase in obesity prevalence in adult men and women 1,2. Parallel to this increase in obesity prevalence, a "body cult" (featuring the adoption of certain foods and practices considered adequate for achieving the goal of a slim body) has become fashionable. However, this fad does not correspond to the fundamental principles of healthy eating habits. The mass communications media thus publicize a concern over body weight by which consumers are encouraged to lose weight (whether they need to or not), perhaps motivated more by the fad itself than any real awareness of obesity-related risks. Individuals thus find themselves surrounded by all kinds of weight-reduction diets in non-scientific publications. The frequency with which such diets are publicized led to this study, aimed at evaluating weight-loss diets published in mainstream non-scientific publications and targeting the adult female public, in relation to total energy value, macronutrients, calcium, iron, vitamins $\mathrm{A}$ and $\mathrm{E}$, and cholesterol content, as well as to verify the presence of information regarding the duration of diets, fluid intake, physical activity, and maintenance diets. 


\section{Methods}

Four non-scientific monthly periodicals targeting the adult female public and which routinely focus on nutrition and other health topics were identified through data supplied by a media research institute called the Instituto Verificador de Circulação. Of the four, two were selected because they published a routine section on diets. Periodical A, with a circulation of 309,110 , has been published for 13 years. Periodical B, with a circulation of 120,000 and an estimated 388,000 readers, has been published for 6 years. Both publications feature at least 7 weight-reduction diets per issue, and the period covered was 8 consecutive months in 2002 , with the issues coinciding for the two periodicals. Hence, 112 weight-reduction diets were analyzed. For the dietary calculation, the Virtual-Nutri software version 1.0 was used 3 , and the following percentages of total energy value (TEV) were considered adequate: 55\%-60\% carbohydrates, $10 \%-15 \%$ proteins, $25 \%-30 \%$ lipids 4 , and $\leq 300 \mathrm{mg}$ cholesterol 5 . Mineral and vitamin contents were compared to the DRIs (Dietary Reference Intakes), including the UL (Tolerable Upper Intake Levels), for women ranging from 19 to 50 years 6,7,8. Instructions on the diet's duration, fluid intake, physical activity, and maintenance diet were also analyzed. Periodical A always stated the diets' total energy value as being $1,200 \mathrm{Kcal}$, while periodical $\mathrm{B}$ stated the expected weekly body weight decrease $(1 \mathrm{~kg}, 1.5 \mathrm{~kg}$, or $2.0 \mathrm{~kg} /$ week).

\section{Results and discussion}

The diets' TEV calculation from both periodicals showed a wide variation (from 565.1 to $2,627.8 \mathrm{Kcal}$ ), and only 13 out of 56 diets from periodical A actually provided some $1,200 \mathrm{Kcal}$ as declared. A very low TEV of $<1,000 \mathrm{Kcal}$, when used, has highly specific indications, since it can be associated with metabolic complications 9 and requires professional follow-up. It is thus hazardous to publicize such a diet in nonscientific publications. Considering different percentages of excess weight and physical activity, it is not safe to affirm the expected weight loss determined by a specific energy deficit, as claimed in the diets in periodical B. Less than $25 \%$ of the diets presented macronutrient energy percentages within the reference values. In relation to cholesterol, $91 \%$ of the diets presented adequate values; however, within those diets, 34 were identified with very low cholesterol content, ranging from 4.84 to $98.07 \mathrm{mg}$
(Table 1). For weight-reduction diets, both the decrease in total energy and a balanced diet are important. Thus, taking into account the lowest energy value, a balanced diet is a guarantee that the body uses macronutrients properly without leading to metabolic alterations 4 . A high energy percentage from carbohydrates ( $>65 \%$ up to $79.05 \%$ ) combined with a low energy percentage from lipids (from $6.08 \%$ to $18.97 \%$ ) was found in 7 diets from periodical A and 9 from periodical B. These were vegetarian diets with fiber content ranging from 41.45 and $57.63 \mathrm{~g}$ (data not shown). Although presenting proper protein content, considering the low digestibility and limited amino acid profile of plant proteins, in addition to the excessively high fiber content, the protein content of these diets may actually be insufficient to attain the protein needs for maintaining a proper nitrogen balance 10 . Also, in view of a possible reduction in mineral absorption induced by high dietary fiber intake 11, extremely fiber-rich diets should be avoided. In all cases the inadequate energy percentage from proteins was represented by numbers greater than the reference values ( $>15 \%$ to $32.28 \%$ ). Within a low overall energy level, this proportionally high-protein diet may mean that the protein will be used as an energy source 12; if the overall energy value is high, the proportion of lipids will also be above the recommended level. Both cases mean a high renal osmotic load 13 . In relation to the energy percentage from lipids, there were inadequacies including both high levels (30\%-42.73\% in 16 diets) and low levels $(<25 \%$ in 79 diets, reaching an insignificant $6.08 \%$ ). Depending on the duration of the diet, the individual's health may be jeopardized by the high intake mainly of saturated and trans fatty acids, leading to increases in circulating lipids 14 , or by low intake, due to the resulting lower consumption of fat-soluble vitamins and essential fatty acids. The high cholesterol content of 9 diets is inconsistent with current scientific knowledge on the subject. Several studies indicate a strong direct association between serum cholesterol concentration and coronary artery disease 15 and thus the importance of maintaining this concentration within adequate levels. Several measures are indicated for this purpose, one of which refers to diet changes, among which the control of cholesterol intake up to $300 \mathrm{mg} /$ day. On the other hand, the literature does not report studies with very low cholesterol intake, the results of which might provide backing for a better analysis of this type of diet's use (e.g., the 34 identified in this study). The mineral and vitamin content of most diets was inadequate (Table 1). 
Diet distribution from periodicals $A$ and $B$ in relation to percentage adequacy of macronutrients, cholesterol, calcium, iron, vitamins $A$ and $E$, and maximum intake levels.

\begin{tabular}{|c|c|c|c|}
\hline Diets from periodicals $A$ and $B(n=112)$ & Adequate (n) & Inadequate $(n)$ & $\geq$ Maximum intake level ( $n$ ) \\
\hline Carbohydrate energy [55\%-60\%] & 21 & $91(31.18 \%-79.05 \%)$ & \\
\hline Protein energy [10\%-15\%] & 27 & $85(11.27 \%-31.21 \%)$ & \\
\hline Lipid energy [25\%-30\%] & 17 & 95 (6.08\%-42.73\%) & \\
\hline Cholesterol (mg) $[\leq 300 \mathrm{mg}]$ & $103(4.84-292.03)$ & 9 (308.19-682.64mg) & \\
\hline Calcium $(m g)^{\star}$ & $16(1,059.8-2,381.1)$ & $95(139.2-961.7)$ & $1(3,035.8)$ \\
\hline $\operatorname{Iron}(\mathrm{mg})^{\star}$ & $3(19.3-36.6)$ & $109(2.55-17.8)$ & - \\
\hline Vitamin A ( $\mu \mathrm{g}$ retinol)* & $78(714.1-2,975.8)$ & $17(334.5-691.8)$ & $17(3,143.1-5,794.42)$ \\
\hline Vitamin E (mg $\alpha$-tocopherol)* & $9(15.1-65.0)$ & $103(1.6-14.8)$ & - \\
\hline
\end{tabular}

* According to the Dietary Reference Intakes.

[ ] = reference values; ( $)=$ observed variation.

Of the 112 diets, 95 presented low calcium content and one showed a value greater than the maximum intake level (3,035.8mg). As for iron, 109 diets presented values below the recommended intake level. In iron deficiency, absorptive efficiency increases, but this response may not be sufficient to prevent anemia in individuals whose available iron intake is marginal, as in the case of the diets analyzed here. The fact that vitamin $\mathrm{E}$ is predominately distributed in lipid-rich foods and vitamin A is found in other types of foods as well may explain the larger number of diets (103) with low vitamin E content (between 1.6 and $14.8 \mathrm{mg} \alpha$ tocopherol) and the larger number of diets (78) with adequate vitamin A content. Nevertheless, of the 78 diets adequate in vitamin A, 42 had more than double the recommended amount, varying from 1,400 to $3,000 \mu$ g retinol. A total of 17 diets also showed vitamin A above the maximum intake level ( $>3,000 \mu$ g retinol), while 17 diets showed low vitamin A values, from 334.5 to $691.8 \mathrm{mg}$ retinol. High and low amounts of minerals or vitamins are undesirable situations, and may cause, respectively, deficiency and negative interactions with other vitamins and/or minerals 16,17 . Only one diet, from periodical B, proved to be balanced, with 1,387.3Kcal, $57.83 \%$ carbohydrates, $15.51 \%$ proteins, $26.66 \%$ lipids, and $278.22 \mathrm{mg}$ cholesterol, and adequate in terms of iron $(19.36 \mathrm{mg})$, calcium $(1,145.5 \mathrm{mg})$, and vitamin $\mathrm{E}$ (26.62mg $\alpha$-tocopherol). In relation to vitamin A, this diet showed 2,338.56 $\mu \mathrm{g}$ retinol, more than triple the recommended amount and very close to the maximum intake level. Finally, no instructions were provided together with the weight-reduction diets in either publication. First, in relation to duration of the diets: the magazines normally provide 7 different diets, one for each day of the week, clearly an insufficient time span to lose weight gradually and adequately. Although a 7 -day diet may lead to a 2 or $3 \mathrm{~kg}$ weight loss, the latter results mainly from the elimination of water in glycogen deposits 18 and is readily recovered once the diet is abandoned. Second, in relation to water intake, under normal conditions water requirements include $1 \mathrm{ml} / \mathrm{Kcal}$ of expended energy and increase under other conditions such as vegetarian or high-protein diets or physical exercise 19. Third, regarding physical exercise, it is known that resistance exercise fosters lean mass preservation/hypertrophy during energy restriction and weigh decrease 20 . The combination of weekly frequency, intensity, heart rate, and duration of exercise is also important. Fourth, regarding the maintenance diet, the diets provide no indication of which measures should be taken to avoid gaining the kilograms lost.

\section{Conclusions}

Non-scientific publications should not be allowed to advertise weight-loss diets, which may influence the adoption of risky eating practices, resulting in harmful effects on health due to the low/high intake of specific nutrients. In addition, the diets analyzed here present inadequate chemical composition and are not accompanied by important instructions for this type of treatment. 


\section{Resumo}

Diversas dietas para redução de peso, anunciadas em periódicos não-científicos de grande circulação, foram avaliadas em relação ao teor energético e de macronutrientes, cálcio, ferro, vitaminas A e E, colesterol e presença de informações sobre a duração da dieta, ingestão de fluidos, atividade física e dieta de manutenção. Duas publicações foram selecionadas em função da periodicidade, tiragem, número de leitores e anos de publicação. Foi utilizado o programa Virtual Nutri para medir os nutrientes de 112 dietas. Os teores de micronutrientes foram comparados com as Dietary Reference Intakes. Todas as dietas eram inadequadas em relação a uma ou mais substâncias avaliadas. Menos de 25,0\% das dietas apresentaram distribuição adequada de macronutrientes. Predominavam os níveis inadequados de cálcio, ferro e vitamina $E(85,7$, 97,3, e 91,9\%, respectivamente). Não deveria ser permitido que publicações não-científicas anunciassem dietas para perda de peso que não apresentassem também uma composição química adequada.

Dieta; Perda de Peso; Valor Nutritivo; Publicações

\section{References}

1. Monteiro CA, Mondini L, de Souza AL, Popkin BM. The nutrition transition in Brazil. Eur J Clin Nutr 1995; 49:105-13.

2. Monteiro CA, Benício MH, Conde WL, Popkin BM. Shifting obesity trends in Brazil. Eur J Clin Nutr 2000; 54:342-6.

3. Philippi ST, Szarfac SC, Laterza CR. Sistema de análise nutricional. Virtual Nutri. Versão 1.0. São Paulo: Universidade de São Paulo; 1996.

4. World Health Organization. Diet, nutrition and the prevention of chronic diseases. Geneva: World Health Organization; 1990. (WHO Technical Report Series 797).

5. National Cholesterol Education Program. Third report of the expert panel on detection, evaluation and treatment of high blood cholesterol in adults (Adult Treatment Panel III). JAMA 2001; 285:2486-97.

6. Institute of Medicine. Dietary reference intakes for calcium, phosphorus, magnesium, vitamin D and fluoride. Washington DC: National Academy Press; 1999

7. Institute of Medicine. Dietary reference intakes for vitamin C, vitamin E, selenium and carotenoids. Washington DC: National Academy Press; 2000.

8. Institute of Medicine. Dietary reference intakes for vitamin A, vitamin $\mathrm{K}$, arsenic, boron, chromium, copper, iodine, iron, manganese, molybdenum, nickel, silicon, vanadium, and zinc. Washington DC: National Academy Press; 2002.

9. Dwyer JT, Lu D. Popular diets for weight loss: from nutritionally hazardous to healthful. In: Stunkard AJ, Wadden TA, editors. Obesity: theory and therapy. New York: Raven Press; 1993. p. 231-49.

10. Young VR, Pellett P. Plant proteins in relation to human protein and amino acid nutrition. Am J Clin Nutr 1994; 59 Suppl 1:203S-12S.

\section{Contributors}

O. M. S. Amancio conceived and designed the study. D. M. A. Chaud collected the data. Both authors conducted the data analysis and interpretation and wrote the article.
11. Weaver CM, Plawecki KL. Dietary calcium: adequacy of a vegetarian diet. Am J Clin Nutr 1994; 59 Suppl 1:238S-41S.

12. Organización Panamericana de la Salud. Conocimientos actuales sobre nutrición. Washington DC: Organización Panamericana de la Salud; 1991. (Publicación Científica 532).

13. Smoyer WE, Brouhard BH, Rassin DK, Lagrone L. Enhanced GFR response to oral versus intravenous arginine administration in normal adults. J Lab Clin Med 1991; 118:166-75.

14. Judd JT, Clevidence BA, Muesing RA, Wittes J, Sunkin ME, Podiczasy JJ. Dietary trans-fatty acids: effects on plasma lipids and lipoproteins of healthy men and women. Am J Clin Nutr 1994; 59:861-8.

15. Kannel WB. Range of serum cholesterol values in the population developing coronary artery disease. Am J Cardiol 1995; 76:69C-77C

16. Couzi F, Keen C, Gershwin ME, Mareschi JP. Nutritional implications of the interactions between minerals. Prog Food Nutr Sci 1993; 17:65-87.

17. Lynch SR. Interaction of iron with other nutrients. Nutr Rev 1997; 55:102-10.

18. Olsson KE, Saltin B. Variation in total body water with muscle glycogen changes. Acta Physiol Scand 1970; 80:11-8

19. National Research Council. Recommended dietary allowances. Washington DC: National Academy Press; 1989.

20. Donnely JE, Sharp T, Houmard J, Carlson MG, Hill JO, Whatley JE, et al. Muscle hypertrophy with large-scale weight loss and resistance training. Am J Clin Nutr 1993; 58:561-5.

Submitted on $22 / \mathrm{Jul} / 2003$

Final version resubmitted on $19 / \mathrm{Feb} / 2004$ Approved on 01/Mar/2004 